\title{
PREDICTION OF SOCIAL GOALS ACCORDINGTO THE EXPERIENCE OF PHYSICAL EDUCATION TEACHERS
}

\author{
Antonio BAENA EXTREMERA, Antonio GRANERO-GALLEGOS, \\ Clara BRACHO-AMADOR, Francisco Javier PÉREZ-QUERO \\ University of Murcia \\ Murcia (Santiago de la Ribera), Spain \\ E-mail: abaenaextrem@um.es
}

\begin{abstract}
The aim was to analyze the relationship of prediction of social goals as teacher experience and perceived motivational climate, discipline strategies and attitudes of students in Physical Education (PE). The sample consisted of 2002 students between 12-19 years of age. A questionnaire consisting of: Social Goals in PE Scale, Learning Orientation Questionnaire and Performance in PE Classes, Teacher Strategies for Maintaining Discipline in Class Scale and Student Conduct towards Teachers and Content in PE Program attitudes Questionnaire. We performed a linear regression analysis using the teacher experience variable selection and social goals. The job climate is a predictor of social goals throughout the teacher's career. As the years pass, teachers should continue to work, making sure students have a good attitude towards the teacher and towards the PE, and not only in the first part of their work experience. Also, one should make an effort to maintain a discipline based on intrinsic reasons.
\end{abstract}

Keywords: respect, responsibility, motivation, discipline, attitude

\section{Introduction}

The Law 8/2013 of Improving Education Quality [Spanish Education Law] states that the quality of education needs to be improved in Spain and also that it has to reach all youth without exclusions. In order to improve both educational contents and students' learning, teachers have to create a learning environment which helps students but students also have to learn to obey rules and roles (goals), they have to be disciplined and above all, they need to show a positive attitude towards the contents they are learning and the person who is focused on teaching them. These are some of the many variables, which play a decisive role when it comes to producing an effective educational system.
We will refer to the popular Achievement Goal Theory (Ames, 1992a, 1992b; Nicholls, 1989 ) in order to explain some of the aforementioned variables and how and why people behave in achievement settings (Murayama, Elliot, \& Friedman, 2012). Regarding the conceptualization of achievement goals, large differences can be found (see Elliot, 2005; DeShon \& Gillespie, 2005; Maehr \& Zusho, 2009; Pintrich, 2000; and other authors).

According to Ames (1992) and Nicholls (1989), this theory analyzes the different dispositional and environmental factors affecting students' achievement motivation. When they find themselves in achievement environments such as schools, people - students in this case - act motivated by achievement of success understood in terms of personal enrichment and improvement, which entails

DOI: $10.21909 /$ sp.2015.03.695 
efforts and involvement (task oriented goal) or in terms of excelling in relation to others and achieving better results (ego oriented goal). Thus, students will create a subjective perception of success according to the criterion they use to define what accounts for success. This criterion will depend on personal factors (dispositional orientation) and on social and situational factors (motivational climate).

In the case of motivational climate, it is continuously created and affected by factors such as parents, teachers, friends and even the media and can be classified into two types: task or mastery motivational climate and ego or competitive motivational climate. Therefore, the goal of students perceiving a task climate (mastery climate) will be mastering the task we propose to them in class and their sense of competence will be increased once they succeed. By contrast, the goal of students perceiving an ego climate (competitive climate) is to show their competence in relation to the other students and they will associate failure with their lack of ability (González-Cutre, Sicilia, \& Moreno, 2011; Moreno et al., 2013). In spite of this, research of multiple goals has empirically shown that instead of adopting an exclusive goal, many students choose various goals when they engage in learning a task or content (Inglés et al., 2015).

The role PE teachers can play in creating a positive classroom climate is central (Rončević \& Kolić-Vehovec, 2014). Furthermore, this climate can have a direct impact on students' social goals (Papaioannou et al., 2007). Guan, McBride and Xiang (2006a) claim that the responsibility and relational goals are two of the most important goals in $\mathrm{PE}$. The former reflects a desire to obey social rules and the established role, whereas the latter refers to a desire to have good relationships with classmates (Ryan, Hicks, \& Midgley, 1997). Authors like Allen (2003) and Guan, Xiang, McBride and Bruene (2006b) state that although there are still few studies analyzing social goals in PE lessons, it seems that the relational and responsibility goals are associated with positive consequences such as persistence and enjoyment (Wallhead, Garn, \& Vidoni, 2013). In the same line, González-Cutre et al. (2011) and Moreno, González-Cutre and Sicilia (2008) state that the responsibility goal has more positive consequences for learning and is more related to a learning motivational climate. On the other hand, the relational goal is more related to a performance motivational climate and it involves striving to show better skills than the classmates. According to these authors, teachers have to accordingly try to develop responsibility goals in students so as to obtain positive effects in terms of their involvement and learning.

In order to achieve teaching goals in the classroom, it is necessary to create an appropriate motivational climate but discipline control is also crucial, both in terms of teachers' strategies and of the way students perceive them (Papaioannou, 1998; Roache \& Lewis, 2011; Spray, 2002). Moreno, Cervelló, Martínez-Galindo and Alonso (2007b), define discipline as consistent behavior in terms of educational goals in a specific situation in which teachers, education and students themselves relate to each other. Thus, according to Moreno et al. (2007b) incidents resulting from undisciplined behavior reduce academic learning time in PE lessons. By contrast, disciplined behavior increases the time available for students to carry out their task. Consequently, discipline is one of the most im- 
portant pedagogical aspects in the educational process (Gutiérrez \& López, 2012; Kiridis, 1999; Sánchez-Oliva et al., 2012). However, according to Gotzens, Castelló, Genovard and Badía (2003), students and teachers perceive disciplinary behavior in significantly different ways.

Moreno et al. (2007b) show in their study that there are positive and significant relationships between task oriented motivational climate and disciplined behavior in $\mathrm{PE}$ classes and also between ego oriented motivational climate and undisciplined behavior in class.

Furthermore, Figley (1985) and Gutiérrez (2003) state that certain characteristics of teachers such as gender, level of training, experience and behavior have an impact on students' attitudes towards PE. Hellín, Hellín and Moreno (2005) claim that teachers' gender affects students' attitudes towards PE and that the teacher's attitude affects variables such as interest, satisfaction and disciplined behavior in class (Moreno \& Cervelló, 2003). At the same line, Molina and Marques (2009) showed that teacher's experience is an important variable that can play a role in the normal development of the class, including discipline, attitude, and climate of the group. However, teacher's experience has barely been researched, in spite of it being a recognized factor for teaching quality. But, currently in Spanish normative system (Decree 93/2013) has reinforced the need for, a so-called, permanent training teacher; i.e., the need for teachers with many years of teaching experience, which is updated continuously to meet the requirements of students. So far, this variable concerning years of experience has barely been considered among faculty research. The importance of the years of teaching experience and the role this vari- able plays in the quality of teaching throughout the teaching years is well known.

In the Spanish legislation (Decree 93/2013, Law 8/2013 of Improving Education Quality) the need for the so-called teacher training is reinforced; i.e., the need that teachers with many years of experience in teaching study and update their knowledge continuously to meet the requirements of the students. So far, this variable of the years of experience has barely been considered among faculty research studies. For this reason we think that it is important to consider the years of teaching experience, as it is a way to learn the role of this variable in the professor as the years pass by.

Based on this evidence, social goals, motivational climate, discipline and students' attitudes are conditioning factors, which affect learning but we don't know if this depends on teacher experience. Consequently, the aim of this research is to analyze the prediction relationship of social goals based on teachers' working experience and on the perceived motivational climate, discipline strategies and students' attitudes PE classes.

\section{Method}

\section{Participants}

A total of 2002 students participated in this study $(970$ male $=48.5 \% ; 1032$ female $=51.5 \%)$ from 17 High Schools in the provinces of Almería (18.9\%), Córdoba (16.8\%), Granada (9.9\%), Jaén (12.2\%) and Sevilla (42.3\%) in the south of Spain. Age range was 12-19 years old $(M=14.99 ; S D=1.43)$, mean age for male students being $15.06(S D=1.43)$ and $14.93(S D=1.43)$ for female students. These students have a medium economic sociolevel, with a $3 \%$ rate of dropout and $7 \%$ for- 
eign pupils for the class. The classes are mixed (boys and girls), and all pupils have $\mathrm{PE}$ as an obligatory subject.

The distribution according to the teacher's gender was as follows: $84.5 \%$ of students had a male teacher and $15.5 \%$ had a female teacher. The percentage of students whose teacher had 0-10 years of working experience was $59.5 \%, 22.3 \%$ were taught by teachers with $11-20$ years of experience, and $18.2 \%$ of students were in a class with teachers with over 20 years of working experience.

\section{Instruments}

Scale of Social Goals in PE (EMSEF), the Spanish version (Moreno, González-Cutre, $\&$ Sicilia, 2007a) of the original Social Goal Scale-PE (SGE-PE) by Guan, Xiang, McBride and Bruene (2006b). The scale measures the responsibility goal (5 items) and the relational goal (6 items). The answers were collected on a polytomous items scale with a score range between 1 (totally disagree) and 7 (totally agree). The internal consistency analysis was: responsibility goal, $\alpha=.84$; relational goal, $\alpha=.82$.

Learning Orientation Questionnaire and Performance in PE Classes (LAPOPECQ). The Spanish version (Cervelló et al., 2002) of the original Learning and Performance Orientations in PE Classes Questionnaire (Papaioannou, 1994). This scale measures students' perception of the motivational climate in the PE class. It includes 27 items and has two dimensions: perception of learning motivational climate (task climate; 13 items) and perception of performance motivational climate (ego climate; 14 items). The answers were collected on a polytomous items scale with a score range between 1 (totally disagree) and 10 (totally agree). The internal consistency analysis was: learning climate, $\alpha=.91 ;$ performance climate, $\alpha=.88$

Teacher Scale Strategies for Maintaining Discipline in Class (SDSS), the Spanish translation by Gutiérrez (2003) from the original Strategies to Sustain Discipline Scale (Papaioannou, 1998) in its version by Gutiérrez, López and Ruiz (2009) and Moreno et al. (2008). It includes 27 items measuring students' perceptions of the strategies used by teachers to maintain discipline in PE classes. Originally including four factors (Papaioannou, 1998), the Spanish validation for high school students kept three dimensions: teachers' emphasis on the intrinsic reasons to maintain discipline (16 items), teachers' emphasis on introjected reasons to maintain discipline (4 items) and teachers' indifference for maintaining discipline (5 items); two items in the original scale were eliminated (Gutiérrez et al., 2009): "We are reminded that being disciplined is the class standard" and "We are reminded that we have accepted to be disciplined". The answers were collected on a polytomous items scale with a score range between 1 (totally disagree) and 5 (totally agree). Internal consistency was satisfactory: emphasis on intrinsic reasons, $\alpha=.94$; emphasis on introjected reasons, $\alpha=.73$; indifference, $\alpha=.71$.

Questionnaire Attitudes toward Student Conduct Files Teachers and PE Program (CAEFP), the Spanish version (Gutiérrez \& Ruiz, 2009) of the original created by Luke and Cope (1994). This instrument includes 29 items divided into two factors, one of them measuring Students' attitude towards their teacher's behavior (15 items) and the other assessing Attitude towards the PE syllabus (14 items). The answers were collected on a polytomous items scale with a score range 
between 1 (totally disagree) and 5 (totally agree). Internal consistency was: attitude towards teachers' behavior, $\alpha=.92$; attitude towards the PE syllabus, $\alpha=.79$.

\section{Procedure}

Permission was obtained from schools' governing bodies and students were debriefed on the purpose of the study and on their rights as participants, based on the Declaration of Helsinki (2008). This study also received the approval and a favorable report from the Bioethics Commission. The tests were carried out during PE hours with previous agreement with the teacher. Participants had 20-30 minutes to complete the questionnaires. Their answers will remain anonymous.

\section{Statistical Analysis}

Item analysis, homogeneity, internal consistency (Cronbach's alpha) and linear regression were carried out with SPSS 17.0. The statistical descriptions and the asymmetry and kurtosis indices were calculated and they were generally close to zero and $<2.0$, as recommended by Bollen and Long (1994). The factor structure of each instrument was assessed with a CFA using LISREL 8.80.

\section{Psychometric properties of the instru- ments}

Given that the structures underlying each instrument have been consistently determined in the literature, the factor structure of each scale was assessed through a CFA using LISREL 8.80. The LISREL 8.80 (Jöreskog \& Sörbom, 2003) weighted least squares (WLS) assessment method for ordinal vari- ables was used as input. The polychoric correlations matrix and the asymptotic covariance matrix were used for data analysis. Furthermore, the existence of the latent variables according to the original instruments described in the corresponding section was assumed.

Taking into account recommendations, which advise against using a sole global fit measure for the model (Bentler, 2007), each model was evaluated using a combination of absolute and relative fit indices. Among the absolute ones, the $p$ value associated with the chi square statistic $\left(\chi^{2}\right)$ was used. The ratio between $\chi^{2}$ and degrees of freedom $(d f)$ $\left(\chi^{2} / d f\right)$ is a heuristic value, which is used to reduce the sensitivity of $\chi^{2}$ to the size of the sample. In a perfect model its value would be 1.0 ; the ratios $<2.0$ can be considered as indicators of a very good fit of the model (Tabachnik \& Fidell, 2007), while values $<5.0$ are considered acceptable (Hu \& Bentler, 1999). Furthermore, the GFI (Goodness-ofFit Index) was calculated and authors such as Hooper, Coughlan and Mullen (2008) consider values $\geq .95$ for a better fit of the model. The relative indices used were the NFI (Normalized Fit Index), NNFI (Non Normalized Fit Index) and CFI (Comparative Fit Index). Incremental indices consider that values of $\geq .95$ indicate a good fit (Hu \& Bentler, 1999). Authors such as Kline (2005) recommend using the RMSEA (Root Mean Square Error of Approximation) and, according to $\mathrm{Hu}$ and Bentler (1999) a value of $\leq .06$ would indicate a good fit. The estimated parameters are considered significant when the value associated to the $t$ value is $>1.96(p<.05)$. The indices obtained in the EMSEF reveal an acceptable goodness of fit: $\chi^{2}=144.61, d f=43$, $p<.000, \chi^{2} / d f=3.36, \mathrm{GFI}=.99, \mathrm{NFI}=.96$, $\mathrm{NNFI}=.96, \mathrm{CFI}=.97, \mathrm{RMSEA}=.06$. In the 
LAPOPECQ, the indices show an acceptable fit: $\chi^{2}=725.26, d f=323, p<.000, \chi^{2} / d f=2.24$, $\mathrm{GFI}=.96, \mathrm{NFI}=.93, \mathrm{NNFI}=.96, \mathrm{CFI}=.91$, $\mathrm{RMSEA}=.05$. The SDSS showed a very good fit: $\chi^{2}=388.63, d f=272, p<.000, \chi^{2} / d f=1.42$, $\mathrm{GFI}=.98, \mathrm{NFI}=.92, \mathrm{NNFI}=.97, \mathrm{CFI}=.97$, $\mathrm{RMSEA}=.05$. In the CAEFP fit was acceptable: $\chi^{2}=855.64, d f=376, p<.000, \chi^{2} / d f=$ $2.27, \mathrm{GFI}=.98, \mathrm{NFI}=.92, \mathrm{NNFI}=.95, \mathrm{CFI}=$ $.95, \mathrm{RMSEA}=.04$. This data fits the established parameters and therefore the models proposed can be accepted as good $(\mathrm{Hu} \&$ Bentler, 1999). Furthermore, each of the models analyzed reaches the minimum requirements necessary in order to guarantee the convergent validity of the model (Hair et al., 2009): high standardized factor loads $(>.60$ in all cases) and statistical significance $(t$-value $>1.96)$. Also, the multivariate normality of each of the scales was analyzed based on the PRELIS/LISREL Relative Mul- tivariate Kurtosis test. The Mardia-BasedKappa coefficient of each instrument was: EMSEF, .544; LAPOPECQ, .304; SDSS, .367; CAEFP, .223. The test critical value was 1.96 $(5 \%)$.

\section{Results}

\section{Descriptive Analysis}

The statistics of the different dimensions studies are shown in Table 1. In the case of social goals, mean scores $(M)$ are similar though they are higher in the relational goal. In terms of the perceived climate, the mean was higher in task climate than in ego climate in the population studied. The statistics obtained in teachers' strategies to maintain discipline in class reveal that the emphasis on intrinsic reasons subscale obtained much higher mean scores than the

Table 1 Descriptive statistics of the EMSEF, LAPOPECQ, SDSS and CAEFP subscales

\begin{tabular}{lrrrr}
\hline Subscales & $M$ & $S D$ & Skewness Kurtosis \\
\hline EMSEF & 5.40 & 1.30 & -.72 & -.03 \\
Responsibility goal & 5.49 & 1.28 & -.70 & -.19 \\
Relational goal & & & & \\
LAPOPECQ & 68.86 & 17.97 & -.24 & -.53 \\
Task climate & 54.53 & 17.01 & -.03 & .05 \\
Ego climate & & & & \\
SDSS & 75.84 & 14.97 & -.73 & 1.13 \\
Emphasis on intrinsic reasons & 53.70 & 18.96 & .18 & -.49 \\
Emphasis on introjected reasons & 48.73 & 17.53 & .42 & -.20 \\
Teacher's indifference & & & & \\
CAEFP & 3.93 & 1.05 & -.94 & 1.12 \\
Attitude towards teacher & 3.83 & 1.13 & -.66 & .80 \\
Attitude towards Physical Education Syllabus & & & & \\
\hline
\end{tabular}

Note. $M=$ mean; $S D=$ standard deviation 
other two dimensions. Finally, in the case of students' attitude towards teachers' behavior and the PE schedule, the attitude towards teachers' behavior scored slightly higher than attitude towards the PE schedule.

\section{Multiple Regression Analysis}

A multiple regression analysis was carried out in order to assess the extent to which the different dimensions of the LAPOPEQ, SDSS and CAEFP affect social goals.

Taking into account the discussion in this paper, we analyze the predictive interesting list of some variables in which the teacher's role is important, as the motivational climate in the classroom, strategies to maintain discipline in the classroom, and student attitude toward the behavior of teachers and PE program content regarding social goals (responsibility and relationship). Here, we analyze the variable of interest "teacher experience" and check the predictive relationships that occur in terms of years of teaching experience. For this reason, years of teaching experience was the selection variable. Data was checked for normality and the tolerance and independence index of the variables included in the regression equation was also assessed. The tolerance index showed values ranging between .57 and .96 and the variance inflation factor (VIF) showed values ranging between 1.09 and 1.74 ; these values indicate that the probability of error derived from potential collinearity is ruled out (Gil, 2003; Hair et al., 1999). Furthermore, the Durbin-Watson statistic obtained was 1.75 1.91, which allows data independence to be asserted.

Results showed that the responsibility goal accounts for $34.1 \%-36.3 \%$ of the overall total variance (Table 2 ) and that the rela- tional goal explains $18.3 \%-23.9 \%$ of the total variance (Table 3 ). Table 2 shows that the task climate was a strong predictor of the responsibility goal, regardless of teachers' years of experience $(\beta=.34-.42)$. The ego climate predicts responsibility behavior especially amongst more experienced teachers $(\beta=.15)$. Regarding discipline strategies, only emphasis on intrinsic reasons predicted the responsibility goal amongst students taught by less experienced teachers $(\beta=.12)$, and by teachers with over 20 years of experience $(\beta=.17)$. However, a strong predictive relationship is established between attitude towards $P E$ and the responsibility goal amongst students taught by teachers with less than 21 years of experience and especially by teachers with 11-20 years of experience $(\beta=.30)$.

Regarding the relational goal (Table 3), the task climate was a strong predictor, regardless of the teacher's years of experience $(\beta=.24-.38)$, although the predictive relationship was stronger amongst the most experienced teachers. The ego climate, unlike the responsibility goal, predicts behavior towards relationship only amongst less experienced teachers $(\beta=.16)$. In terms of discipline strategies, no predictive relationship was found with the relational goal. Finally, the attitude towards PE predicts relationship behavior amongst students, whereas a negative prediction relationship is established between attitude towards the teacher and the relational goal.

\section{Discussion}

Set within the framework of achievement goal theories and social goals, this study has analyzed the prediction relationship of social goals according to teachers' work expe- 
Table 2 Multiple regression analysis; LAPOPECQ, SDSS and CAEFP factors act as Social Goals predictors (dependent variable: responsibility goal)

\begin{tabular}{|c|c|c|c|c|c|c|c|c|c|}
\hline \multirow[b]{2}{*}{ Variables } & \multicolumn{3}{|c|}{$\begin{array}{c}0-10 \text { years } \\
\text { of experience } \\
(n=1191)\end{array}$} & \multicolumn{3}{|c|}{$\begin{array}{c}11-20 \text { years of } \\
\text { experience } \\
(n=446)\end{array}$} & \multicolumn{3}{|c|}{$\begin{array}{c}+ \text { of } 20 \text { years of } \\
\text { experience } \\
(n=365)\end{array}$} \\
\hline & $t$ & $\beta$ & $p$ & $t$ & $\beta$ & $p$ & $t$ & $\beta$ & $p$ \\
\hline Task climate & 10.71 & .38 & .000 & 6.99 & .42 & .000 & 5.52 & .34 & .000 \\
\hline Ego climate & 2.12 & .07 & .034 & .14 & .01 & .888 & 2.68 & .15 & .008 \\
\hline Emphasis on intrinsic reasons & 2.59 & .12 & .010 & -.09 & -.01 & .931 & 1.99 & .17 & .048 \\
\hline Emphasis on introjected reasons & .08 & .01 & .939 & .572 & .03 & .568 & .14 & .01 & .891 \\
\hline Teacher's indifference & .496 & .02 & .620 & .832 & .05 & .406 & -.86 & -.06 & .392 \\
\hline Attitude towards teacher & -.08 & -.01 & .932 & -.06 & -.00 & .954 & -.89 & -.08 & .375 \\
\hline $\begin{array}{l}\text { Attitude towards Physical } \\
\text { Education syllabus }\end{array}$ & 3.52 & .16 & .000 & 4.39 & .30 & .000 & 1.84 & .14 & .067 \\
\hline & & $\begin{array}{l}F \\
R^{2}\end{array}$ & $\begin{array}{l}69.07 \\
.344\end{array}$ & & $\begin{array}{l}F \\
R^{2}\end{array}$ & $\begin{array}{l}31.97 \\
.363\end{array}$ & & $\begin{array}{l}F \\
R^{2}\end{array}$ & $\begin{array}{l}24.32 \\
.341\end{array}$ \\
\hline
\end{tabular}

Note. $p$ is significant at level $<.05 ; \beta$ : standardized beta weights $; R^{2}$ : explained total variance

Table 3 Multiple regression analysis; LAPOPECQ, SDSS and CAEFP factors act as Social Goals predictors (dependent variable: relational goal)

\begin{tabular}{|c|c|c|c|c|c|c|c|c|c|}
\hline \multirow[b]{2}{*}{ Variables } & \multicolumn{3}{|c|}{$\begin{array}{c}0 \text {-10 years of } \\
\text { experience } \\
(n=1191)\end{array}$} & \multicolumn{3}{|c|}{$\begin{array}{c}11-20 \text { years of } \\
\text { experience } \\
(n=446)\end{array}$} & \multicolumn{3}{|c|}{$\begin{array}{c}+ \text { of } 20 \text { years of } \\
\text { experience } \\
(n=365)\end{array}$} \\
\hline & $t$ & $\beta$ & $p$ & $t$ & $\beta$ & $p$ & $t$ & $\beta$ & $p$ \\
\hline Task climate & 8.23 & .31 & .000 & 3.62 & .24 & .000 & 5.66 & .38 & .000 \\
\hline Ego climate & 4.81 & .16 & .000 & 1.86 & .10 & .064 & 1.49 & .10 & .136 \\
\hline Emphasis on intrinsic reasons & 1.61 & .08 & .109 & 1.40 & .12 & .160 & -.39 & -.04 & .693 \\
\hline Emphasis on introjected reasons & .30 & .01 & .765 & 1.70 & .10 & .090 & -.73 & -.05 & .468 \\
\hline Teacher's indifference & .01 & .00 & .990 & -.04 & -.01 & .966 & 1.00 & .07 & .317 \\
\hline Attitude towards teacher & -.21 & -.15 & .031 & -2.65 & -.26 & .008 & -1.13 & -.11 & .259 \\
\hline $\begin{array}{l}\text { Attitude towards Physical } \\
\text { Education syllabus }\end{array}$ & 3.39 & .22 & .001 & 3.42 & .26 & .001 & 1.58 & .13 & .114 \\
\hline & & & $\begin{array}{c}41.39 \\
.239\end{array}$ & & $\begin{array}{l}F \\
R^{2}\end{array}$ & $\begin{array}{c}12.48 \\
.190 \\
\end{array}$ & & $\begin{array}{l}F \\
R^{2}\end{array}$ & $\begin{array}{l}10.55 \\
.183 \\
\end{array}$ \\
\hline
\end{tabular}

Note. $p$ is significant at level $<.05 ; \beta$ : standardized beta weights ; $R^{2}$ : explained total variance 
rience, taking into account the motivational climate perceived in PE classes, the strategies developed by teachers to maintain discipline and students' attitudes towards PE. The results of this paper provide a new insight about teacher experience as a variable of interest in order to measure other learning variables, as it is analyzed in this paper. It is interesting to note that teacher experience has not been studied before in this context, including Spanish school.

The task motivational climate has a positive relationship with task oriented goals (Moreno et al., 2007a; Guang et al., 2006b). A number of different studies have shown that the task climate predicts the responsibility goal, regardless of teachers' work experience and so have the results obtained in other studies such as Cecchini et al. (2008) and Guang et al. (2006b), who state that one of the predictors of achievement results in $\mathrm{PE}$ classes is persistence and effort, inherent to the task climate. However, the task climate also predicts the relational goal in teachers so it is worth noting, in view of the results obtained, that regardless of years of experience, the task climate predicts both the responsibility and the relational goal, in line with the studies by Newton, Watson, Kim and Beacham (2006) and Ommundsen and Roberts (1999). Nowadays, the benefits of task climate in PE are known, but these results show that this variable does not depend of teacher experience. Thus MartínezGalindo, Alonso, Moreno and Cervelló (2009) and Papaioannou and Goudas (1999) claim that when teachers plan lessons with a great variety of significant tasks in which personal improvement and cooperation among students prevail and use different strategies, students also perceive a caring teacher, intrinsically motivated to promote discipline in class, which in turn improves attitudes towards PE; this claim is in line with the results in this study.

Furthermore, contrary to the findings in Martínez-Galindo, Alonso, Cervelló and Moreno (2005) and Moreno et al. (2008), in this study the performance climate predicts responsibility behavior, especially amongst the most experienced teachers. We can think that these teachers have the capacity to plan their lessons with an authority approach, i.e. students have to follow their role and the rules (inherent to this goal) and are grouped according to their level of ability. Evaluation is carried out according to victory or defeat and is based on comparison and the distribution of practice time is the same for everyone (Guzmán \& García-Ferriol, 2002). In this case, the teacher experience should be considered in PE field to achieve this goal, as the results show.

Intrinsic reasons to maintain discipline in class predict the responsibility goal, which is understandable as according to Anderman and Anderman (1999), this would prove that subjects with responsibility social goals value learning and personal improvement to a greater extent, which is in line with intrinsic reasons for maintaining discipline. This tendency is explained in MartínezGalindo et al. (2005), who claim that as discipline reasons become less self-determined, psychological mediators gradually lose prediction capacity. Thus, following Spray and Wang (2001) and Spray (2002), the most selfdetermined reasons, such as the responsibility goal, were keeping with disciplined behavior, whereas the less self-determined ones corresponded with undisciplined behavior. This situation occurs specifically in the case of the least experienced teachers and with teachers with over 20 years of ex- 
perience. Perhaps, these results should make us reflect about what happens in the half-life of teacher experience, and the changes in PE efficacy. In spite of this situation, these results are in line with those obtained by Moreno et al. (2007a), who perceive that the responsibility goal is related to some positive consequences (effort, persistence and interest in learning), which brings about better discipline in the classroom. Likewise, Cecchini et al. (2001) claim that the task climate improves students' perceived competence, their efforts, enjoyment and intrinsic motivation so that the task climate predicts the responsibility goal as well.

Furthermore, the relational goal is predicted by attitude towards PE and has a negative relationship with attitude towards the PE teacher. As stated before, the task climate predicts the relational goal in all teachers (regardless of teacher experience), and González-Cutre et al. (2011), Moreno et al. (2008) and Morgan and Carpenter (2002), have shown that a task motivation climate is related to positive consequences in the behavioral and affective sphere, such as the use of effective learning strategies and positive attitudes towards the subject, specifically towards PE. In this regard, Moreno, Cervelló, Zomeńo and Marín (2009) state that the climate created by PE teachers may or may not trigger certain disciplined behaviors according to its nature.

These results therefore indicate that teachers should develop responsibility goals in students so as to achieve positive effects in terms of their involvement and learning (Moreno et al., 2007a) and create task and learning motivated climates to improve students' attitudes towards physical activity (Gutiérrez, Ruiz, \& López, 2011).
According to Dixon and Wilke (2007), experience has an impact on professional improvement only when knowledge is elaborated and built upon; it is never a question of mere accumulation. To conclude this study, it is safe to state that teachers' experience is related to students' opinion of PE classes. Therefore, both proper initial PE teacher training and continuing education are important in acquiring good expertise by building upon it in a meaningful way, not by the mere accumulation of working years.

Furthermore, through teachers' working years, the task climate predicts both responsibility and relational social goals, whereas as teachers gain more and more experience in PE lessons, they gradually succeed at making the ego climate become a significant predictor of the responsibility goal. On the other hand, it is during the first working years when the ego climate predicts the relational goal. Moreover, attitude towards the PE syllabus is an important predictor of students' social goals amongst teachers with less than 20 years of experience, whereas attitude towards teachers is important for the relational goal. Thus, teachers should continue to work over the years on improving students' attitude both towards the teacher and PE, rather than focusing on this only during their initial working years. Likewise, in terms of discipline, only intrinsic reasons are predictors of the responsibility goal, especially when the teacher has few years of experience. Efforts should be made to maintain this kind of discipline in class.

In the practice, teachers should seek a taskclimate in their classes, due to other positive prediction variables. For it, formation courses of didactic and teaching in PE are necessary as continuous formation, regardless of teachers' years of experience. Thus, the students 
can see teachers carefully preparing their lessons, improving students' attitudes towardPE.

Finally, it is worth noting that this study is novel in that it shows students' different opinions in terms of the expertise in education of their teachers. Also, this work shows that some variables change with the years of experience and it is necessary to be aware of it and act accordingly. This study can be raise teachers' own reflection on their performance in the classroom, as Korthagen (2010) says. Also, for students, it is important that the PE teacher renew his/her methodology and teaching resources (Reyno et al., 2014).

Received October 20, 2014

\section{References}

Allen, J. B. (2003). Social motivation in youth sport. Journal of Sport and Exercise Psychology, 25(4), 551-567.

Ames, C. (1992a). Achievement goals, motivational climate, and motivational processes. In G. Roberts (Ed.), Motivation in sport and exercise (pp. 161-176). Champaign, IL: Human Kinetics.

Ames, C. (1992b). Classrooms: Goals, structures, and student motivation. Journal of Educational Psychology, 84, 261-271.

Anderman, L. H., \& Anderman, E. M. (1999). Social predictors of changes in students' achievement goal orientations. Contemporary Educational Psychology, 25, 21-37.

Bentler, P. M. (2007). On tests and indices for evaluating structural models. Personality and Individual Differences, 42, 825-829.

Bollen, K., \& Long, J. S. (1994). Testing structural equation models. Newbury Park, CA: Sage.

Cecchini, J. A., González, C., Carmona, A. M., Arruza, J. A., Escartí, A., \& Balaguer, G. (2001). The influence of the physical education teacher on intrinsic motivation, self-confidence, anxiety, and pre- and post-competition mood states. European Journal of Sport Science, 1(4), 1-11.

Cecchini, J. A., González, C., Méndez, A., Fernández-Río, J., Contreras, O., \& Romero, S. (2008). Metas sociales y de logro, persistencia- esfuerzo e intenciones de práctica deportiva en el alumnado de Educación Física. Psicothema. 20(2), 260-265.

Cervelló, E., Jiménez, R., Fenoll, A., Ramos, L., Del Villar, F., \& Santos-Rosa, F. J. (2002). A social-cognitive approach to the study of coeducation and discipline in Physical Education Classes. SOCIOTAM, Revista Internacional de Ciencias Sociales y Humanidades, 11, 43-64.

Decree 93/2013 of 27 August, on the initial and ongoing training of teachers in the Autonomous Community of Andalusia is regulated as well as the Andalusian System Teacher Training (BOJA 30/08/2013).

Deshon, R. P., \& Gillespie, J. Z. (2005). A motivated action theory account of goal orientation. Journal of Applied Psychology, 90, 10961127.

Dixon, P., \& Wilke, R. A. (2007). The influence of a teacher research experience on elementary teachers' thinking and instruction. Journal of Elementary Science Education, 19(1), 25-43.

Elliot, A. J. (2005). A conceptual history of the achievement goal construct. In A. Elliot, \& C. Dweck (Eds.), Handbook of competence and motivation (pp. 52-72). New York: Guilford Press.

Figley, G. E. (1985). Determinants of attitudes toward physical education. Journal of Teaching in Physical Education, 4, 229-240.

Gil, J. A. (2003). Métodos de investigación en educación. Análisis multivariante (Vol. III). Madrid: UNED.

González-Cutre, D., Sicilia, A., \& Moreno-Murcia, J. A. (2011). Un estudio cuasi-experimental de los efectos del clima motivador tarea en las clases de educación física. Revista de Educación, 356, 677-700.

Gotzens, C., Castelló, A., Genovard, C., \& Badía, M. (2003). Percepciones de profesores y alumnos de E.S.O. sobre la disciplina en el aula. Psicothema, 15(3), 362-368.

Guan, J., McBride, R. E., \& Xiang, P. (2006a). Reliability and validity evidence for the Social Goal Scale-Physical Education (SGS-PE) in high school settings. Journal of Teaching in Physical Education, 25, 226-238.

Guan, J., Xiang, P., McBride, R., \& Bruene, A. (2006b). Achievement goals, social goals and students' reported persistence and effort in high school physical education. Journal of Teaching in Physical Education, 25, 58-74.

Gutiérrez, M. (2003). Manual sobre valores en la educación física y el deporte. Barcelona: Paidós. 
Gutiérrez, M., \& López, E. (2012). Motivational climate, reasons for discipline and behavior in physical education. International Journal of Medicine and Science of Physical Activity and Sport, 12(46), 235-251.

Gutiérrez, M., \& Ruiz, L. M. (2009). Perceived motivational climate, sportsmanship, and students' attitudes toward physical education classes and teachers. Perceptual and Motor Skills, 108, 308-326.

Gutiérrez, M., López, E., \& Ruiz, L. M. (2009). Estrategias para mantener la disciplina en las clases de educación física: Validación de su medida y análisis de la concordancia entre las percepciones de los profesores y las de sus alumnos. Revista Mexicana de Psicología, 26(2), 203-212

Gutiérrez, M., Ruiz, L. M., \& López, E. (2011) Clima motivacional en Educación Física: Concordancia entre las percepciones de los alumnos y las de sus profesores. Revista de Psicología del Deporte 20(2), 321-335.

Guzmán, J. F., \& García-Ferriol, A. (2002). Orientación de meta de los entrenadores y metodología de entrenamiento: implicaciones motivacionales. Motricidad, 9, 65-82.

Hair, J. F., Anderson, R. E., Tatham, R. L., \& Black, W. C. (1999). Multivariate Data Analysis. Upper Saddle River, NJ: Prentice-Hall.

Hair, J. F., Black, W. C., Babin, B. J., \& Anderson, R. E. (2009). Multivariate Data Analysis (7th ed.). New York: Pearson Prentice Hall.

Hellín, G., Hellín, P., \& Moreno, J. A. (2005). Valoración de la educación física según el género del profesor. In A. Díaz (Ed.), V Congreso Internacional de Educación Física e Interculturalidad. Murcia: ICD.

Hooper, D., Coughlan, J., \& Mullen, M. (2008). Structural equation modelling: Guidelines for determining model fit. Electronic Journal of Business Research Methods, 6(1), 53-60.

Hu, L., \& Bentler, P. M. (1999). Cutoff criteria for fit indexes in covariance structure analysis: Conventional criteria versus new alternatives. Structural Equation Modelling, 6, 1-55.

Inglés, C. J., Martínez-Monteagudo, M. C., GarcíaFernández, J. M., Valle, A., \& Castejón, J. L. (2015). Goal orientation profiles and self-concept of secondary school students. Journal of Psychodidactic, 20(1), 99-116.

Jöreskog, K. G., \& Sörbom, D. (2003). LISREL 8.54. Structural equation modeling with the
Simplis command language. Chicago: Scientific Software International.

Kiridis, A. (1999). Discipline at School. Athens: Gutenberg.

Kline, R. B. (2005). Principles and practice of structural equation modeling (2nd Ed.). New York: The Guilford Press.

Korthagen, F. A. J. (2010). La práctica, la teoría y la persona en la formación del profesorado. Revista Interuniversitaria de Formación del Profesorado, 68(24,2), 83-101.

Law 8/2013 of Improving Education Quality. (B.O.E., $\mathrm{n}^{\circ} 295,10$ of December).

Luke, M. D., \& Cope, L. D. (1994). Student attitudes toward teacher behavior and program content in school physical education. Physical Educator, 51(2), 57-66.

Maehr, M. L., \& Zusho, A. (2009). Achievement goal theory. The past, present, and future. In K. R. Wentzel, \& A. Wigfield (Eds.), Handbook of motivation at school (pp. 77-104). New York: Routledge.

Martínez-Galindo, C., Alonso, N., Cervelló, E., \& Moreno, J. A. (2005). La disciplina en Educación Física según el género del alumno y el tipo de centro. In A. Díaz (Ed.), V Congreso Internacional de Educación Física e Interculturalidad. Murcia: ICD.

Martínez-Galindo, C., Alonso, N., Moreno, J. A. \& Cervelló, E. (2009). Perfiles motivacionales y disciplina en clases de educación física. Diferencias según las razones del alumnado para ser disciplinado y la percepción del trato generado por el profesorado en el aula. Cultura $y$ Educación, 21(3), 331-343.

Molina, J., \& Marques, C. (2009). Teaching experience in physical education and pupils with special educational needs: A study of correlation. Retos, 16, 16-21.

Moreno, J. A., \& Cervelló, E. (2003). Pensamiento del alumno hacia la Educación Física: Su relación con la práctica deportiva y el carácter del educador. Enseńanza, 21, 345-362.

Moreno, J. A., Cervelló, E., Martínez-Galindo, C., \& Alonso, N. (2007b). Los comportamientos de disciplina e indisciplina en educación física. Revista Iberoamericana de Educación, 44, 167190.

Moreno, J. A., Cervelló, E., Zomeńo, T., \& Marín, L. M. (2009). Predicción de las razones de disciplina en Educación Física. Acción Psicológica, 6(2), 7-15 
Moreno, J. A., González-Cutre, D., \& Sicilia, A. (2007a). Metas sociales en las clases de educación física. Análisis y Modificación de Conducta, 33, 351-368.

Moreno, J. A., González-Cutre, D., \& Sicilia, A. (2008). Metas de logro $2 \times 2$ en estudiantes espańoles de Educación Física. Revista de Educación, 347, 299-317.

Moreno, J. A., Zomeńo, T. E., Marín, L. M., \& Cervelló, E. (2013). Percepción de la utilidad e importancia de la educación física según la motivación generada por el docente. Revista de Educación, 362, 380-40.

Morgan, K., \& Carpenter, P. (2002). Effects of manipulating the motivational climate in physical education lessons. European Physical Education Review, 8, 207-229.

Murayama, K., Elliot, A. J., \& Friedman, R. (2012) Achievement goals and approach avoidance motivation. In R. M. Ryan (Ed.), The Oxford handbook of human motivation (pp. 191-207). Oxford: Oxford University Press.

Newton, M., Watson, D. L., Kim, M. S., \& Beacham, A. O. (2006). Understanding motivation of underserved youth in physical activity settings. Youth and Society, 37, 348-371.

Nicholls, J. G. (1989). The competitive ethos and democratic education. Cambridge, MASS: Harvard University Press.

Ommundsen, Y., \& Roberts, G. C. (1999). Effect of motivational climate profiles on motivational indices in team sport. Scandinavian Journal of Medicine and Science in Sports, 9, 389-397.

Papaioannou, A. (1994). Development of a questionnaire to measure achievement goals in physical education. Research Quarterly for Exercise and Sport, 65, 11-20.

Papaioannou, A. (1998). Goal perspectives, reasons for going disciplined and self-reported discipline in physical education lessons. Journal of Teaching in Physical Education, 17, 421-441.

Papaioannou, A., \& Goudas, M. (1999). Motivational climate of the physical education class. In Y. V. Auweele, F. Bakker, S. Biddle, M. Durand, \& R. Seiler (Eds.), Psychology for physical educators (pp. 51-68). Leeds: Human Kinetics.

Papaioannou, A. G., Tsigilis, N., Kosmidou, E., \& Milosis, D. (2007). Measuring perceived motivational climate in physical education. Journal of Teaching in Physical Education, 26, 236259.
Pintrich, P. R. (2000). Multiple goals, multiple pathways: The role of goal orientation in learning and achievement. Journal of Educational Psychology, 92, 544-555.

Reyno, A., Arias, R., Cuneo, F., Figueroa, C., \& Rojas, P. (2014). Pedagogical features that a physical education teacher should have. Habilidad Motriz, 43, 4-11.

Roache, J. E., \& Lewis, R. (2011). The carrot, the stick, or the relationship: What are the effective disciplinary strategies? European Journal of Teacher Education, 34(2), 233-248.

Rončević, B., \& Kolić-Vehovec, S. (2014). Perceptions of contextual achievement goals: Contribution to high-school student's achievement goal orientation, strategy used and academic achievement. Studia Psychologica, 56(2), 137-153.

Ryan, A. M., Hicks, L., \& Midgley, C. (1997). Social goals, academic goals and avoiding seeking help in the classroom. Journal of Early Adolescence, 17, 152-171.

Sánchez-Oliva, D., Leo, F. M., Amado, D., GonzálezPonce, I., \& López, J. M. (2012). Differential analysis of perception of the development of values in Physical Education classes. Retos, 22, 9-12.

Spray, C. (2002). Motivational climate and perceived strategies to sustain pupils' discipline in physical education. European Physical Education Review, 8, 5-20.

Spray, C. M., \& Wang, C. K. J. (2001). Goal orientations, self determination and pupils' discipline in physical education. Journal of Sports Sciencies, 19, 903-913.

Steiger, J. H. (2007). Understanding the limitations of global fit assessment in structural equation modeling. Personality and Individual Differences, 42(5), 893-98.

Tabachnick, B. G., \& Fidell, L. S. (2007). Using Multivariate Statistics ( $5^{\mathrm{a}}$ ed.). New York: Allyn and Bacon.

Wallhead, T. L., Garn, A. C., \& Vidoni, C. (2013). Sport education and social goals in physical education: Relationships with enjoyment, relatedness, and leisure-time physical activity. Physical Education and Sport Pedagogy, 18(4), 427441 .

World Medical Association (2008). Declaration of Helsinki (revised 7 May 2012). Retrieved from: http://www.wma.net/es/30publications/10policies/ b3/17c_es.pdf 


\section{PREDIKCIA SPOLOČENSKÝCHCIEL'OV PODL'A SKÚSENOSTÍUČITEL'OV TELOCVIKU}

A. B. Extremera, A. Granero-Ga 11 egos, C. Bracho-A m a dor, F. J. P ér e z-Q u e r o

Súhrn: Ciel'om štúdie bola analýza vzt'ahov predikcie spoločenských ciel’ov ako skúsenost' učitel'ov a vnímané motivačné prostredie, disciplinárne stratégie a postoje študentov $\mathrm{k}$ telesnej výchove. Výskumný výber tvorilo 2002 študentov vo veku 12 - 19 rokov. Administrovali sme: Social Goals in PE Scale, Learning Orientation Questionnaire and Performance in PE Classes, Teacher Strategies for Maintaining Discipline in Class Scale, Student Conduct towards Teachers and Content in PE Program attitudes Questionnaire. Výber premenných skúseností učitel'ov a spoločenské ciele sme spracovali pomocou lineárnej regresnej analýzy. Pracovné prostredie je prediktorom spoločenských ciel'ov v priebehu celej profesionálnej kariéry učitel'a. S pribúdajúcimi rokmi by mali učitelia nad'alej pracovat', snažit' sa o dobrý vzt'ah žiakov k učitel'om a k telesnej výchove, a to nielen $v$ počiatočnej fáze ich práce. Okrem toho by sa mali snažit’ udržiavat' disciplínu založenú na vnútorných princípoch. 